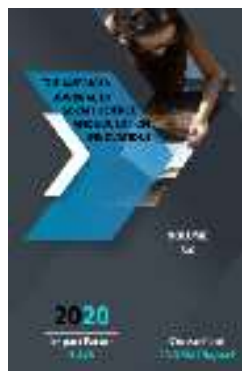

\title{
Some Thoughts On The Evolution Of Approaches To The Concept Of Human Capital
}

\author{
Muhriddin Mahamadaminovich Sodirjonov \\ Researcher, Namangan State University, Uzbekistan
}

Journal Website:

http://usajournalshub.c

om/index,php/tajssei

Copyright: Original

content from this work

may be used under the

terms of the creative

commons attributes

4.0 licence.

\section{ABSTRACT}

The article presents an analysis of research and scientific-theoretical solutions and proposals of foreign researchers in the field of studying the processes of human capital development. Comments on the conceptual views of economists and sociologists on the development of human capital are given.

\section{KEYWORDS}

Human capital, labor, sociology, economics, society, innovation, education, health, ability, investment.

\section{INTRODUCTION}

The main factor in the development of modern society is education, health, professionalism, creativity, as well as the scientific and innovative development of information, technologies.

Every social phenomenon in society arises as an element of the social system, and human capital becomes its main object. Human capital - requires constant development and investment, thereby forming various sectors and indicators of society. To date, a number of books, scientific papers and dissertations have been written on the concept of human capital. All of them are doing research to create more opportunities for people, to make life easier, and to find answers to questions about when everything will be fine. 
Improving human capital is one of the most important scientific and practical issues in the study of socio-economic and political relations in the country.

From the second half of the twentieth century, attitudes toward human capital and education began to change radically. Theoretical and practical aspects of human capital development were first studied by foreign economists - scientists A.Smith, T.Shults, G.Becker, E.Denison, R.Solou, S.Fisher [1]. According to T. Schultz [2], it allows for a consistent distribution of capital: human capital and material capital [3.45]. G.
Becker [4], one of the theorists of human capital, was the first to apply the concept of human capital at the micro level.

\section{THE MAIN FINDINGS AND RESULTS}

A. Smith emphasizes the importance of human capital in the process of upbringing a person, developing his ability to work, as well as his specialization for the benefit of society [5]. We believe that human capital was measured by the ability to work to create new value from the point of view of the time.

\section{Views of economists on human capital}

\begin{tabular}{|c|c|c|}
\hline Economists & Economic views of economists on human capital & $\begin{array}{l}\text { The uniqueness of economic } \\
\text { views }\end{array}$ \\
\hline $\begin{array}{l}\text { A. Smith } \\
(1723-1790)\end{array}$ & $\begin{array}{l}\text { The increase in production depends primarily on the } \\
\text { capacity of the employee, and then on the fact that } \\
\text { the employee is armed with tools. }\end{array}$ & $\begin{array}{l}\text { Particular attention is paid } \\
\text { to the individual } \\
\text { characteristics of people, } \\
\text { and this factor is associated } \\
\text { with labor productivity. }\end{array}$ \\
\hline $\begin{array}{l}\text { T. Shults } \\
(1902-1998)\end{array}$ & $\begin{array}{l}\text { Improving the well-being of the poor depends on } \\
\text { knowledge, not on land or technology. }\end{array}$ & $\begin{array}{l}\text { People's level of education } \\
\text { depends on their income } \\
\text { level. }\end{array}$ \\
\hline $\begin{array}{l}\text { E. Denison } \\
(1915-1992)\end{array}$ & $\begin{array}{l}\text { The cost factor of human capital is not a primary } \\
\text { factor, but their resulting quality indicators are one } \\
\text { of the key factors of economic growth. }\end{array}$ & $\begin{array}{l}\text { Emphasis is placed on the } \\
\text { efficiency of human capital } \\
\text { development expenditures. }\end{array}$ \\
\hline $\begin{array}{l}\text { G. Becker } \\
(1930-2014)\end{array}$ & $\begin{array}{l}\text { General education is equally beneficial for all firms } \\
\text { and increases the productivity of workers, while } \\
\text { special education serves to increase the productivity } \\
\text { of the firm that provides training, which is superior } \\
\text { to other forms of training. In a competitive } \\
\text { environment, the level of wages is determined by } \\
\text { high productivity and applies to the entire firm. } \\
\text { Therefore, the firm is not in favor of pure "general } \\
\text { education" overhead. }\end{array}$ & $\begin{array}{l}\text { People's professionalism } \\
\text { and level of specialization } \\
\text { are considered to be the } \\
\text { main factors of competitive } \\
\text { advantage. }\end{array}$ \\
\hline S.Fisher (1943) & $\begin{array}{l}\text { The ability that can bring income to a person is } \\
\text { human capital. Human capital is classified as innate } \\
\text { ability, talent, as well as learned (acquired). }\end{array}$ & $\begin{array}{l}\text { The role and importance of } \\
\text { internal (innate) and } \\
\text { external (lifelong) factors in } \\
\text { the formation of human } \\
\text { capital are highlighted. }\end{array}$ \\
\hline
\end{tabular}


According to S.Voronina's interpretation of human capital, the level of health of the population is a particularly important issue, which is the basis of socio-economic development in any country. It is the level of health of the population that forms human capital [6. 141].

I.V. Ilinsky believes that human capital consists of educational capital, health capital and cultural capital [7.127].

The principle of a functional approach should be taken into account for a broader analysis of the composition of human capital. The methodological principle of the functional approach requires that the phenomenon be considered not only in terms of its internal structure, but also in terms of its functional purpose, the ultimate use purpose.

According to the Russian economist S.A. Dyatlov, according to this principle, human capital is a certain reserve of health, knowledge, skills and abilities, motivation, formed as a result of investment and accumulated by man. When this reserve is used in a certain sphere of social production, it helps to increase labor productivity and production efficiency, which in turn affects the increase in wages (income) of the individual [8.72].

V.T. Smirnov and I.V. Skoblyakova argue that human capital should be valued at the level of an individual, an individual enterprise or a group of enterprises [9].

The theory, scientific and practical aspects of "human capital" in our country, the development of human capital in Uzbekistan in a market economy and the improvement of its investment practices, the mechanism and support for strong social policy were developed by Uzbek economists, L.M. Toshpolatova, N. Abdullaeva, Q.X. Abdurahmanov [10.542], Problems related to the improvement of marketing services in the market of educational services A.V Vakhabov, Sh.Sh.Shodmonov, H.P. Researched by Abdulkasimov, T.T Juraev, S.S Gulomov, E.G Nabiev, G.N Akhunova, M.H Saidov, A.S Kucharov, K.S Alimdjanov, M. Saidov, A.O Ergashev, G.S Kasimova and A.H Eshboev [11]. Human capital has also been studied from a social point of view by M. Bekmurodov [12], M. Kuronov [13], A. Umarov, U. Hayitov, M. Abdujabbarova and others.

The history of world economics the economic literature states that until the beginning of the twentieth century, physical capital, ie the means of production, material resources played a key role in the production process. By the middle of the twentieth century, the rapid development of science and technology has brought knowledge, research, and human potential to the forefront. Direct man has become the driving force of economic development. The category of "human capital" began to form in economics. Its emergence was a response to the demands of economics and life of economics and related sciences.

An in-depth study of the pace of development of society and the economy, as well as the intellectual potential accumulated by man and him, has become a vital necessity.

In the social sciences of the Western world in general, human capital is not interpreted as a great opportunity to improve the spiritual and moral condition of society, to create prosperity, to mobilize people for creative work. In the process of work, a person does not have the opportunity to understand himself as an integral part of the community, society, as well as a person who consciously benefits those around him.

Human capital is a set of human qualities. It means his ability to work in society and in the institution, his position in production, which is a source of income for himselfs. 
Human capital is a resource that shapes human beings as they develop all areas of society and the country.

Resources or resources accumulated in a person are a certain level of health, skills, experience, potential, acquired knowledge and profession, ability to work, and similar human characteristics.

The following arguments are identified as evidence:

- It takes the form of basic capital because of a person's ability in society. The richness of a person's abilities and position in life, his personality, is a natural human skill. These features cannot be taken or sold in isolation.

- The qualities of a person's creativity are the qualities that enable him to achieve great material and spiritual benefits in the future.

- Human's creative ability is not only material, but also spiritual, social and spiritual.

- For the formation of creative ability in a person, society must attract the necessary requirements for each individual. It must be spent. (Every individual must pay attention to himself in the investment for the formation of human capital, not only the individual, but also society, the state must take certain measures.

- Typically, the elements of human capital include:

- Educational capital, based on general and specialized knowledge,

- Preparatory capital in the production process (degree, skill, production experience);

- Health capital;

- Acquiring income-generating, growthgenerating, economically relevant information.
The following indicators can be used to assess human capital on an individual basis:

$$
\begin{aligned}
& \text { - Structure of organization and } \\
& \text { management of human resources; } \\
& \text { - Satisfaction with life, the level of } \\
& \text { gratitude; } \\
& \text { - Level of education; } \\
& \text { - Profession, experience; } \\
& \text { - High spirituality and culture; } \\
& \text { - Time and cost of education; } \\
& \text { - Health, prevention; } \\
& \text { - } \quad \text { Activity, ability and talent; }
\end{aligned}
$$

Human capital is a social factor that has a significant impact on the country's innovation. The following properties of human capital can be distinguished:

First, human capital is inseparable from its owner - an enterprise worker or a resident of the region;

Second, the major part of the human capital (which is why it is sometimes called the health capital), which includes the physiological characteristics and natural abilities of man, is inherited from generation to generation; the other part in the form of knowledge, skills, and competencies is bestowed as a result of the aspirations of the individual and society; Thirdly, human capital, like other capital, can be used in the field of social production and is one of the most important factors in increasing its efficiency;

Fourth, human capital is used by its owner for the purpose of making a profit, so the increase in income justifies the fact that individuals increase their intellectual power through the acquisition of knowledge and skills.

The main aspects of human capital are defined as follows:

I. Sources of a certain level of knowledge, skills, and different levels of production qualities and human potential formed in the process of investing in a person; 
II. Based on the accumulated knowledge, a person develops slowly and develops himself in one or another area of development in society.

III. Based on the accumulated skills, a person achieves a balanced wealth, and in the form of a monthly salary, he and the society's national income is created.

IV. By investing in it, the society is coordinated to ensure the growth of income, its acquisition of new knowledge, skills and experience in the future.

Human capital is a set of human qualities. It means his ability to work in society and in the institution, his position in production, which is a source of income for himselfs. Human capital is a resource that shapes human beings as they develop all areas of society and the country. Resources or resources accumulated in a person are a certain level of health, skills, experience, potential, acquired knowledge and profession, ability to work, and similar human characteristics.

Socio-economic development - human capital can be achieved only through the formation of knowledge, skills, qualities, abilities and skills that provide personal and social well-being. Education is a key factor in shaping human capital. People are choosing to get a quality education and a modern career. Indeed, the process of globalization is fueling the need for technological skills and developing opportunities to increase the importance of human capital.

\section{CONCLUSION}

Unfortunately, today for many people this opportunity is not considered sufficient for the full development or realization of their abilities and talents. Even in developed countries, one fifth of young people cannot complete secondary school, which seriously limits their opportunities for further employment. This failure often leads to certain communities separating them from the economic and social flow.

Globalization is a complex and controversial phenomenon that encompasses a wide range of social, political, cultural and economic spheres, and has led to the disappearance of a simple truth in the nature of trends: national boundaries. Signs of globalization can be seen everywhere - the rapid spread of technology is permeating the processes of cultural universalization.

Poverty doesn't just mean, no money; which means a shortage.

Knowledge enables the use of existing opportunities in society, while skills provide social development and economic growth. This phenomenon requires constant funding for education.

This was once a decisive factor for success. It is important to work in factories, to be comfortable and close to a natural place for boat or train stations.

Human capital is the level of personal, social and economic well-being at which a person possesses knowledge, skills and abilities.

Every developed country has paid special attention to the cost of education in the first place. The list goes on and on, with the United States, Germany, Japan, Singapore and more. As a result of the development of mass education around the United States, largescale economic growth was achieved in the late 19 th century.

In recent years, the "Asian Tiger" is considered a priority policy of the state for quality education on the basis of socioeconomic prosperity of Singapore and Korea. Long before children go to school, they begin to develop. Since childhood, every parent strives to constantly improve the knowledge 
and skills of his child. They recognize the importance of paying special attention to improving their reproductive status and intellectual potential. Investing in children's health and education helps them to develop human capital. Economists have proven that spending or investing in education at a young age is justified, and various theoretical and practical studies have been developed.

\section{REFERENCES}

1. Smith A. Research on the nature and causes of the wealth of nations. Moscow: Eksmo. 2007. -p. 684// Shultz T. Human Capital in the International Encyclopedia of the Social Sciences. N.Y. 1968. vol. 6 // Becker G. Human Capital. NY: Columbia University Press. 1964. // Denison E. "Analysis of US economic growth from 1929 to 1969" (Accounting for United States Economic Growth. 1929-69, 1974. p. 576) // Solou R. Policy of Full Employment. 1962. -p. 638 // Fisher S; Dornbusch R; Schmalenzi R. Economic theory. Moscow: Unity, 2002. -p. 378

2. Theodore William Schultz (April 30, 1902, Arlington: February 26, 1998. Ivanston, USA) was an American economist who was awarded the 1979 Nobel Prize for his research on economic development in developing countries. Major works: Food for the World (1945); Transformation of Traditional Agriculture (1964).

3. Shultz T. Human Capital, family planning and their etfects on population growth // American Economic Review. 1994. May. p. 45.

4. Gary Stanley Becker (born December 2, 1930) is an American economist who won the 1992 Nobel Prize for "applying the field of microeconomic analysis to a number of human characteristics" Major works: The Economic Theory of
Discrimination (1957), Human Capital (1964), Economic Theory (1971).

5. Smith A.An Inquiry into the Nature and Causes of the Wealth of Nations Book2 of the Nature, Accumulation, and Employment of Stock. London: 1776.

6. Voronina S.Yu. Economic foundations of the functioning of autonomous institutions in the field of health services: diss. Ph.D. St. Petersburg: SP GEMU. 2014. -p. 141.

7. Ilyinsky I.V. Investing in the Future: Education in Investment Reproduction. SPb: SPbUEF, 1996. -p. 127.

8. Dyatlov S.A. Human Capital Theory: Textbook. SPb: SPbUEF. 1996. -p. 72.

9. Smirnov V.T; Skoblyakova I.V. Classification and types of human capital in an innovative economy. SPb: Prospect, 2001. - p. 2003.

10. Toshplatova L.M. Human development: textbook / number of authors 2nd edition. Tashkent: UWED, UNDP. 2011. pp. 357-363 // Abdullaeva N. Human development: textbook / number of authors 2nd edition. Tashkent: UWED, UNDP. 2011. -pp. 11-48 // Human development. Textbook. prof. Edited by Q.H Abdurahmanov. Tashkent: Economy. 2013. -p. 542.

11. Vakhabov A.V; Imamov E; Soleev A; Tulyakhodzhaeva $M$; Khusanova $N$. Higher education in Central Asia. Modernization tasks. Tashkent: 2007. -p. 214; Shodmonov Sh.Sh. Economic theory. Tashkent: 2002. -p. 240. Abdulqosimov H.P. The human factor in the emerging market economy and ways to activate it Tashkent: TMI. 2005. -p. 196; S. S. Gulomov Education in Uzbekistan, today's day. Moscow: Alma-mater, 2001 .; Nabiev E. The sphere of services in national reproduction: abstract of a doc.of economic sciences. Tashkent: 
Tashkent State University. 1994. -p. 36.;

Akhunova G.K Marketing activities in the market of educational services and its improvement: author's ref. i.f.d. Tashkent: TDIU. - p. 46.; Saidov M.X. Economics, investment and marketing of higher education: Tashkent: Finance, 2002. -p. 332.; Kucharov A.S. Improving the organizational and economic factors of management in the training of highly educated professionals for the business sector: i.f.d. abstracts. Tashkent: TDTU, 2006. -p. 40.; Alimdjanov K.S. National training program of the Republic of Uzbekistan and issues of its financial support: i.f.n. diss. Abstract. Tashkent: TDIU, 2004 -p. 23 ; Ergashev A.O. Improving the basics of economic management of the education system (on the example of secondary special, professional system): - i.f.n. abstract Tashkent: TDTU, 2006. -p. 24.; Qosimov $G$. The role of budget policy in the development of socio-cultural spheres: i.f.n. diss. Abstracts. Tashkent: TDTU, 2001. -p. 25.; Eshboev A.X. The impact of the education system on the development of the national economy during the transition to market relations: i.f.n. diss. abstracts. Tashkent: National University of Uzbekistan, 2008. -p. 25.

12. Bekmurodov M.M. Human capital is a factor of development. Tashkent: "Manaviyat". 2015

13. Kuronov M. Human capital is the spiritual capital of the economy. Interaction of the family, Continuing education institutions, Neigborhood and law enforcement agencies in the prevention of juvenile delinquency and neglect Materials of the Republican scientific-practical conference April 18-19 Gulistan: 2014. -pp. 22-26

14. Yusupalieva D. K; Sodirzhonov M. M.(2017). Mass media in Uzbekistan: development trends, dynamics and prospects. Modern Science, (1), -pp. 2325. 